\title{
Resveratrol inhibits oligomeric A $\beta$-induced microglial activation via NADPH oxidase
}

\author{
YAO YAO ${ }^{1,2^{*}}$, JUAN LI $^{3,4^{*}}$, YANG NIU $^{5,6}$, JIAN-QIANG YU ${ }^{3,7}$, LING YAN $^{1}$, ZHEN-HUA MIAO $^{1}$, \\ XUN-XIAZHAO ${ }^{1}$, YUAN-JIE LI ${ }^{1}$, WAN-XIA YAO ${ }^{3}$, PING ZHENG $^{3}$ and WEI-QI LI ${ }^{8,9}$ \\ ${ }^{1}$ Department of Medical Chemistry, School of Basic Medical Science; ${ }^{2}$ Research Center of Medical Science and Technology; \\ ${ }^{3}$ Department of Pharmacology, School of Pharmacy, Ningxia Medical University, Yinchuan, Ningxia 750004; \\ ${ }^{4}$ Ningxia Engineering and Technology Research Center for Modernization of Hui Medicine, Yinchuan, Ningxia 750004; \\ ${ }^{5}$ Department of Basic Traditional Chinese Medicine, School of Traditional Chinese Medicine, Ningxia Medical University, \\ Yinchuan, Ningxia 750004; ${ }^{6}$ Key Laboratory of Hui Medicine Modernization, Ministry of Education, Yinchuan, Ningxia 750004; \\ ${ }^{7}$ Ningxia Collaborative Innovation Center for Hui Medicine, Yinchuan, Ningxia 750004; ${ }^{8}$ National Resource Center \\ of Chinese Materia Medica, Academy of Chinese Medical Sciences, Beijing 100700; \\ ${ }^{9}$ China National Center for Biotechnology Development, Beijing 100039, P.R. China
}

Received October 9, 2014; Accepted June 25, 2015

DOI: $10.3892 / \mathrm{mmr} .2015 .4199$

\begin{abstract}
Microglia-mediated neuroinflammation is key in the pathogenesis of Alzheimer's disease (AD). Several studies have suggested that NADPH oxidase contributes to microglia-mediated neuroinflammation. Resveratrol, which is a natural polyphenolic compound, exerts neuroprotective effects in AD due to its anti-inflammatory properties. The present study aimed to investigate the effects of resveratrol on the activation of oligomeric amyloid $\beta$ (oA $\beta$ )-induced BV-2 microglia, and to determine the role of NADPH oxidase in these effects. Microglial proliferation was measured by high-content screening cell counting and using a bromodeoxyuridine incorporation assay. In addition, the levels of reactive oxygen species (ROS), nitric oxide (NO), tumor necrosis factor (TNF)- $\alpha$ and interleukin (IL)-1 $\beta$ were assessed. The results of the present study demonstrated that resveratrol inhibited the proliferation of $\mathrm{oA} \beta$-induced microglia and the production of pro-inflammatory factors, including ROS, NO, TNF- $\alpha$ and IL-1 $\beta$. Subsequent mechanistic investigations demonstrated that resveratrol inhibited the oA $\beta$-induced mRNA and protein expression levels of $\mathrm{p} 47$ phox and gp91phox. These results suggested that NADPH oxidase may be a potential target
\end{abstract}

Correspondence to: Dr Wei-Qi Li, China National Center for Biotechnology Development, 4th Building, 16 West Fourth Ring Road, Beijing 100039, P.R. China

E-mail: liwq@cncbd.org.cn

*Contributed equally

Key words: resveratrol, Alzheimer's disease, BV-2 microglia, oligomeric amyloid $\beta$, NADPH oxidase for AD treatment, and resveratrol may be a valuable natural product possessing therapeutic potential against AD.

\section{Introduction}

Alzheimer's disease (AD), which is the most common age-associated neurodegenerative disorder, causes progressive dementia, and microglia-mediated neuroinflammation is key in the pathogenesis of AD (1). Microglia are the resident immune cells of the brain, which are important in host defense and tissue repair in the central nervous system (2). In response to brain injury or immunological stimuli, including amyloid $\beta(\mathrm{A} \beta)$ or lipopolysaccharide (LPS), microglia are activated, producing various pro-inflammatory mediators, including tumor necrosis factor- $\alpha(\mathrm{TNF}-\alpha)$, interleukin- $1 \beta$ (IL-1 $\beta$ ), nitric oxide (NO), and reactive oxygen species (ROS) (3). Accumulation of these mediators contributes to neuronal damage and aggravates AD progression. Therefore, the production of inflammatory factors by microglia requires inhibition to prevent neuroinflammation and neurodegeneration in AD.

Resveratrol (3,4',5-trihydroxy-trans-stilbene), which is a natural, nonflavonoid, polyphenolic compound, is present in several plant species, including giant knotweeds, peanuts, mulberries and grapes, and is found in red wine (4). Evidence suggests that resveratrol exerts neuroprotective effects against neurodegenerative diseases, due to its anti-inflammatory properties $(5,6)$. In vitro studies have demonstrated that resveratrol inhibits the production of LPS-induced NO and TNF- $\alpha$ in murine microglial cells $(7,8)$, as well as the production of prostaglandin E2 and free radicals in rat primary microglia (9). In addition, previous studies have demonstrated that resveratrol prevents microglial activation and subsequent inflammatory-mediator release by inhibiting transcriptional factors, including nuclear factor- $\kappa \mathrm{B}(10,11)$. The neuroprotective effects of resveratrol have been detected in numerous 
studies; however, the mechanisms underlying its beneficial effects remain poorly understood.

NADPH oxidase has been confirmed as an important contributor to microglia-mediated neuroinflammation and neurodegeneration $(12,13)$. Previous studies have demonstrated that soluble oligomeric (o)A $\beta$, which is present in the cortex of patients with $\mathrm{AD}$, exhibits more marked correlation with $\mathrm{AD}$ symptoms, compared with fibrillar $\mathrm{A} \beta$ in amyloid plaques $(14,15)$. Using the BV-2 murine microglial cell line, our previous study demonstrated that oA $\beta$ induced the activated properties of microglia, and activation was inhibited by the NADPH oxidase inhibitors, diphenyleneiodonium (DPI) and apocynin. These results suggested that NADPH oxidase may be involved in the activation of $\mathrm{oA} \beta$-induced microglia (16). The present study aimed to use BV-2 microglia cultures to investigate the inhibitory effects of resveratrol on the activation of $\mathrm{oA} \beta$-induced microglia and further investigate the role of NADPH oxidase.

\section{Materials and methods}

Regents. Dulbecco's modified Eagle's medium and fetal bovine serum were purchased from Gibco Life Technologies (Grand Island, NY, USA). Resveratrol, 2', 7'-dichlorodihydrofluorescein diacetate (DCFH-DA), DPI, Hoechst 33258 and Hoechst 33342 were purchased from Sigma-Aldrich (St. Louis, MO, USA). Mouse monoclonal anti-bromodeoxyuridine (BrdU) antibody (1:200; cat. no. MS-1508; Lab Vision, Fremont, CA, USA), polyclonal fluorescein isothioyanate (FITC)-conjugated goat anti-mouse immunoglobulin G (1:200; cat. no. F9006; Sigma-Aldrich) were used, and 1,1,1,3,3,3-hexafluoro-2-propanol (used in oA $\beta$ preparation) was obtained from J\&K Scientific Ltd. (Beijing, China). Mouse monoclonal anti-gp91phox and rabbit anti-p47phox (1:200, cat. no. sc-74514: Santa Cruz Biotechnology, Inc. (Dallas, TX, USA). TNF- $\alpha$ and IL-1 $\beta$ ELISA kits were purchased from Diaclone (Besançon, France), and the BrdU cell proliferation ELISA kit was purchased from Roche Diagnostics (Mannheim, Germany).

Preparation of peptides. The A $\beta 1-42$ peptide was purchased from AnaSpec (Fremont, CA, USA). OA $\beta$ was prepared as follows. Briefly, A $\beta 1-42$ peptide was dissolved in $1 \mathrm{mM}$ 1,1,1,3,3,3 hexafluoro-2-propanol, immediately aliquoted, and dried under a vacuum. The residual peptide was stored at $-20^{\circ} \mathrm{C}$ and subsequently dissolved in DMSO to $5 \mathrm{mM}$, which was then diluted with Millipore water (EMD Millipore, Billerica, MA, USA) to a final concentration of $50 \mu \mathrm{M}$ prior to use. The oA $\beta$ fraction was obtained following $24 \mathrm{~h}$ of gentle agitation at $4^{\circ} \mathrm{C}$ and the conformation was confirmed using atomic force microscopy (Dimension 3100; Veeco, Plainview, NY, USA), as described in our previous study (16).

Cell culture. BV-2 murine microglial cells were provided by Professor Y. C. Kim (Seoul National University, Seoul, South Korea). The cells $\left(5 \times 10^{4}\right.$ cells $\left./ \mathrm{ml}\right)$ were cultured, as described in our previous study (16). The BV-2 murine microglial cells were obtained by immortalization of primary murine microglial cultures with a v-raf/v-myconcogene-containing retrovirus (J2), which retained the majority of the morphological, phenotypic and functional properties of freshly isolated microglia.
The BV-2 cells were cultured in Dulbecco's modified Eagle's medium supplemented with $10 \%$ heat-inactivated fetal bovine serum at $37^{\circ} \mathrm{C}$ in a humidified $5 \% \mathrm{CO}_{2}$ atmosphere. Stock cells were passaged two to three times per week with a 1:5 split ratio and used within six passages.

Measurement of BrdU incorporation using ELISA. The BV-2 cells $\left(5 \times 10^{4}\right.$ cells $\left./ \mathrm{ml}\right)$ were plated into 96 -well microtiter plates. The microglial cells were then treated with $20 \mu \mathrm{g} / \mathrm{ml}$ oA $\beta$, either alone or in combination with resveratrol $(0.3,1,3,10$ or $30 \mu \mathrm{M})$. Following $24 \mathrm{~h}$ incubation, the cells were assessed, as described previously (16). Briefly, following $24 \mathrm{~h}$ incubation, the cells were assessed for novel DNA synthesis using a BrdU cell proliferation ELISA kit (Roche Diagnostics, Mannheim, Germany). BrdU $(10 \mu \mathrm{M})$ was added to the plate for $2 \mathrm{~h}$, following which the cells were fixed, according to the manufacturer's instructions. BrdU incorporation was detected by the addition of anti-BrdU antibody with peroxidase activity. Substrate solution was added, and the resultant color was measured using a Biotek Synergy HT plate reader (Biotek Instruments, Winooski, VT, USA) at absorbance wavelengths of 370 and $492 \mathrm{~nm}$.

Cell count determination using a high-content screening (HCS) system. The BV-2 cells were incubated under the same conditions and with the same treatments as were used for the measurement of BrdU incorporation. The number of microglial cells was measured using an IN Cell Analyzer 2000 HCS system (GE Healthcare Life Sciences, Little Chalfont, UK), as described previously (16).

Fluorescence imaging of the double-labeled microglial cells, acquired using the HCS system. The BV-2 cells $\left(5 \times 10^{4}\right.$ cells $\left./ \mathrm{ml}\right)$ were plated into 96 -well microtiter plates. The microglial cells were then treated with oA $\beta(20 \mu \mathrm{g} / \mathrm{ml})$, either alone or with resveratrol $(3,10$ or $30 \mu \mathrm{M})$. Following $24 \mathrm{~h}$ incubation, new DNA synthesis of the microglia was examined, as described previously (16). Briefly, following $24 \mathrm{~h}$ incubation, novel DNA synthesis of microglia was examined by adding $\operatorname{BrdU}(10 \mu \mathrm{M})$ to the culture medium. Following another $24 \mathrm{~h}$ culture, the cells were fixed in $4 \%$ paraformaldehyde at $4^{\circ} \mathrm{C}$. After $30 \mathrm{~min}$, the paraformaldehyde was removed, followed by three washes with PBS. The preparations were treated with $\mathrm{HCl}(2 \mathrm{M})$ for $20 \mathrm{~min}$, sodium borate $(0.1 \mathrm{M})$ for $15 \mathrm{~min}$, and $0.2 \%$ Triton $\mathrm{X}-100$ for $10 \mathrm{~min}$ at room temperature $(\mathrm{HCl}$, sodium borate and Triton X-100 were all from Sigma-Aldrich). Following each step, the plates were washed three times with PBS. Subsequently, nonspecific binding sites were blocked with $5 \%$ bovine serum albumin in PBS. Microglial cells were then successively incubated in mouse monoclonal anti-BrdU antibody overnight at $4^{\circ} \mathrm{C}$ and FITC-conjugated goat anti-mouse IgG for $1 \mathrm{~h}$. Cultures processed without the primary antibody or without BrdU were devoid of labeling, which indicated the absence of nonspecific labeling. Cell nuclei were stained with Hoechst 33342. Fluorescence images were acquired using the IN Cell Analyzer 2000 system with the following filter sets: Excitation, 360 and $480 \mathrm{~nm}$; emission, 460 and $535 \mathrm{~nm}$. Fluorescence images were captured using the IN Cell Analyzer 2000 system with the following filter sets: Excitation, 360 and $480 \mathrm{~nm}$; emission, 460 and $535 \mathrm{~nm}$. 
Measurement of intracellular ROS. The levels of intracellular ROS were measured using a DCFH-DA oxidation assay. The BV-2 cells were plated into 96-well microtiter plates at a density of $3 \times 10^{5}$ cells $/ \mathrm{ml}$ and treated with oA $\beta(20 \mu \mathrm{g} / \mathrm{ml})$ for $2 \mathrm{~h}$, either alone or in combination with resveratrol $(1,3,10$ or $30 \mu \mathrm{M})$ or DPI $(5 \mu \mathrm{M})$. Following treatment, the cells were washed with phosphate-buffered saline. DCFH-DA $(20 \mu \mathrm{M})$ was then added, and the cells were incubated for $40 \mathrm{~min}$ at $37^{\circ} \mathrm{C}$. Fluorescence was measured using a Biotek Synergy 2 plate reader (Biotek Instruments) at an excitation wavelength of $485 \mathrm{~nm}$ and an emission wavelength of $528 \mathrm{~nm}$.

Determination of nitric oxide $(\mathrm{NO})$ release. The concentration of nitrite $\left(\mathrm{NO}_{2}^{-}\right)$, which accumulated in the culture supernatant fraction was measured, according to the Griess reaction (17). The BV-2 microglia were plated into 96 -well microtiter plates at a density of $3 \times 10^{5}$ cells $/ \mathrm{ml}$ and treated with oA $\beta(20 \mu \mathrm{g} / \mathrm{ml})$ for $24 \mathrm{~h}$, either alone or in combination with resveratrol (1, $3,10$ or $30 \mu \mathrm{M} \mu \mathrm{M})$ or DPI $(5 \mu \mathrm{M})$. Minocycline $(30 \mu \mathrm{M}$; Sigma-Aldrich) was used as a positive control. The culture supernatant fluid $(50 \mu \mathrm{l})$ was then collected from the cells and mixed with $50 \mu \mathrm{l}$ Griess reagent (part I, 1\% sulfanilamide; part II, $0.1 \%$ naphthylethylene diamide dihydrochloride and $2 \%$ phosphoric acid; Sigma-Aldrich) at room temperature. Following 15 min incubation, the absorbance was measured at $540 \mathrm{~nm}$ using a Biotek Synergy HT plate reader (Biotek Instruments).

Determination of $T N F-\alpha$ and $I L-1 \beta$. The BV-2 cells $\left(3 \times 10^{4}\right.$ cells $\left./ \mathrm{ml}\right)$ were incubated under the same conditions and with the same treatments as for the measurement of NO release. The concentrations of TNF- $\alpha$ and IL-1 $\beta$ in the culture medium were measured using ELISA kits, according to the manufacturer's instructions. Briefly, $100 \mu \mathrm{l}$ of each standard, sample and zero were added in duplicate to the appropriate number of wells. Subsequently, $50 \mu$ l diluted biotinylated anti-mTNF- $\alpha$ or biotinylated anti-mIL-1 $\beta$ was added to all wells, covered with a plastic plate cover and incubated at room temperature for $3 \mathrm{~h}$. The cover was then removed and the plate washed, as follows: Liquid was aspirated from each well; $0.3 \mathrm{ml} 1 \mathrm{X}$ washing solution was dispensed into each well; contents of each well were aspirated; and the first two steps were repeated another two times. Subsequently, $100 \mu \mathrm{l}$ streptavidin-horseadish peroxidase solution was added to each well, covered with a plastic plate cover and incubated at room temperature for $30 \mathrm{~min}$. Following incubation, the washing step was repeated and $100 \mu 1$ of ready-to-use 3,3',5,5'-tetramethylbenzidine substrate solution was added into all wells. Following incubation at room temperature in the dark for 10-20 min, $100 \mu 1$ Stop reagent was added to each well, and the absorbance at $450 \mathrm{~nm}$ was measured using a Biotek Synergy HT plate reader.

Semi-quantitative reverse transcription-polymerase chain reaction $(R T-P C R)$ analysis. The $\mathrm{BV}-2$ microglial cells were treated with oA $\beta(20 \mu \mathrm{g} / \mathrm{ml})$, either alone or together with resveratrol $(3,10$ or $30 \mu \mathrm{M})$ or DPI $(5 \mu \mathrm{M})$ for $12 \mathrm{~h}$. Total RNA was extracted from the cells using TRIzol ${ }^{\circledR}$ (Invitrogen Life Technologies, Carlsbad, CA, USA). Total RNA was reverse transcribed using a cDNA First-Strand
Synthesis system (Fermentas, Thermo Fisher Scientific, Inc., Pittsburgh, PA, USA). The PTC-200 PCR system (Bio-Rad Laboratories, Inc., Hercules, CA, USA) was used for the PCR analysis. The quantity of sample analyzed was as follows: cDNA $(1 \mu \mathrm{l}), 1 \mathrm{X}$ PCR buffer $(2.5 \mu \mathrm{l})$, dNTPs $(2.5 \mathrm{mM} ; 2$ $\mu \mathrm{l})$; primers $(10 \mathrm{pmol} ; 1 \mu \mathrm{l})$. The cDNA was amplified by PCR using specific primers for gp91phox, p47phox and GAPDH. The primer sequences were as follows: gp91phox, sense 5'-GCACTGGAACCCCTGAGAAA-3' and antisense 5'-GGTTTATGATGATGGGCCTAA-3'; p47phox, sense 5'-ACATCACAGGCCCCATCATCCTTC-3' and antisense 5'-ATGGATTGTCCTTTGTGCC-3'; and GAPDH, sense 5'-GGTGCTGAGTATGTCATGGA-3' and antisense 5'-TTCAGCTCTGGGATGACCTT-3'. Primers were from Huamei Biotechnology, Ltd. (Wuhan China). The following PCR cycling conditions were applied: gp91phox, 34 cycles of denaturation at $94^{\circ} \mathrm{C}$ for $30 \mathrm{sec}$, annealing at $56^{\circ} \mathrm{C}$ for $30 \mathrm{sec}$ and extension at $72^{\circ} \mathrm{C}$ for $45 \mathrm{sec}$; 47 phox, 28 cycles of denaturation at $94^{\circ} \mathrm{C}$ for $30 \mathrm{sec}$, annealing at $58^{\circ} \mathrm{C}$ for $30 \mathrm{sec}$ and extension at $72^{\circ} \mathrm{C}$ for $45 \mathrm{sec}$; GAPDH, 32 cycles of denaturation at $94^{\circ} \mathrm{C}$ for $30 \mathrm{sec}$, annealing at $55^{\circ} \mathrm{C}$ for $45 \mathrm{sec}$ and extension at $72^{\circ} \mathrm{C}$ for $45 \mathrm{sec}$. The PCR products were then separated on $1.2 \%$ agarose gels, and visualized with ethidium bromide $(0.5 \mu \mathrm{g} / \mathrm{mL}$; Sigma-Aldrich). The mRNA expression levels of GAPDH were used for standardization.

Western blot analysis. In order to determine the protein expression levels of gp91phox and p47phox, the BV-2 microglial cells were treated with oA $\beta(20 \mu \mathrm{g} / \mathrm{ml})$, either alone or together with resveratrol $(3-30 \mu \mathrm{M})$ or DPI $(5 \mu \mathrm{M})$ for $24 \mathrm{~h}$. The cells were then washed with ice-cold PBS and lysed for 10 min using radioimmunoprecipitation lysis buffer (Santa Cruz Biotechnology, Inc.), containing 50 mM Tris- $\mathrm{Cl}$ (pH 7.4), $150 \mathrm{mM} \mathrm{NaCl}, 0.1 \%$ SDS, $1 \%$ NP-40, $1 \%$ sodiumdeoxycholate, $1 \mathrm{mM}$ phenylmethyl-sulfonylfluoride, $1 \mathrm{mM}$ EDTA, $1 \mu \mathrm{g} / \mathrm{ml}$ pepstatin, $1 \mu \mathrm{g} / \mathrm{ml}$ leupeptin and $1 \mu \mathrm{g} / \mathrm{ml}$ aprotinin. The protein concentration in the supernatant fluid of the lysate was measured using a bicinchoninic acid protein assay (Pierce Biotechnology, Inc., Rockford, IL, USA). Equal quantities $(60 \mu \mathrm{g})$ of protein were separated by $12 \%$ SDS-PAGE (Ameresco, Solon, OH, USA) and were then transferred onto $0.45 \mu \mathrm{m}$ polyvinylidene fluoride membranes (EMD Millipore, Bedford, MA, USA). The membranes were then blocked in blocking buffer (5\% skimmed milk) and incubated overnight with primary antibodies at $4^{\circ} \mathrm{C}$, followed by incubation with horseradish peroxidase-conjugated goat anti-mouse (1:2,000; cat. no. A4416) and horseradish peroxidase-conjugated goat anti-rabbit (1:2,000; cat. no. A6154) secondary antibodies for $1 \mathrm{~h}$ at room temperature, obtained from Sigma Aldrich. Following three washes in tris-buffered saline containing $0.1 \%$ Tween 20 (Amaresco), immunoreactive bands were visualized using enhanced chemiluminescence reagent (Beyotime Institute of Biotechnology, Shanghai, China). The protein expression levels of $\beta$-actin were used for standardization.

Statistical analysis. Data are expressed as the mean \pm standard error of the mean of three experiments performed in triplicate. One-way analysis of variance and Student's t-test were used for statistical analysis (SPSS 16.0; SPSS, Inc., Chicago, IL, USA). ImageJ software (version 1.44; National Institutes of Health, 
Bethesda, MA, USA) was used to quantify mRNA and protein levels in the RT-PCR and western blot assays, respectively. $\mathrm{P}<0.05$ was considered to indicate a statistically significant difference.

\section{Results}

Inhibitory effects of resveratrol on oA $\beta$-induced $B V$-2 microglial cell proliferation. Treatment of the cells with $\mathrm{oA} \beta(20 \mu \mathrm{g} / \mathrm{ml})$ for $24 \mathrm{~h}$ induced the proliferation of the cultured microglia; however, this effect was inhibited by various concentrations of resveratrol (Fig. 1A). Furthermore, higher levels of BrdU incorporation were observed when the microglial cells were treated with oA $\beta(20 \mu \mathrm{g} / \mathrm{ml})$ for $24 \mathrm{~h}$, and this effect was also inhibited by resveratrol (Fig. 1B). In controlled trials, resveratrol alone $(30 \mu \mathrm{M})$ did not affect microglial proliferation (Fig. 1A and B); and did not decrease microglial viability, as assessed using an MTT reduction assay (data not shown). The fluorescence images of the microglial cells double-labeled with Hoechst 33342 and BrdU were concordant with the results obtained from the HCS and BrdU assays (Fig. 1C). These results indicated that resveratrol inhibited the proliferation of oA $\beta$-induced microglia.

Inhibitory effects of resveratrol on oA $\beta$-induced $B V-2$ microglial proinflammatory mediator release. In the present study, resveratrol decreased the levels of oA $\beta$-induced ROS in a dose-dependent manner (Fig. 2A). The NADPH-oxidase inhibitor, DPI, was used as a positive control. Neither resveratrol nor DPI had an effect on the production of microglial ROS in the absence of oA $\beta$. In addition, NO secretion increased in response to oA $\beta$ treatment, but was inhibited by resveratrol in a dose-dependent manner (Fig. 2B). MINO was used as a positive control. These data indicated that oA $\beta$-induced NO secretion was inhibited by resveratrol. Furthermore, when the cells were treated with resveratrol in combination with oA $\beta$, a significant inhibition in the production of oA $\beta$-induced TNF- $\alpha$ and IL-1 $\beta$ was observed. By contrast, resveratrol exerted no effect on microglial TNF- $\alpha$ and IL-1 $\beta$ production in the absence of $\mathrm{oA} \beta$ (Fig. $2 \mathrm{C}$ and D). These results suggested that $\mathrm{oA} \beta$ peptide activated the microglia to produce and release ROS, NO, TNF- $\alpha$ and IL-1 $\beta$, and these effects were inhibited by treatment with resveratrol.

Inhibitory effects of resveratrol on oA $\beta$-induced microglial activation may be mediated by NADPH oxidase. NADPH oxidase is the key enzyme, which is required for the production of ROS in activated microglia. The activation of NADPH oxidase requires the p47phox, p67phox and p40phox cytosolic subunits and the p22phox and gp91phox catalytic subunits (18). RT-PCR and western blotting demonstrated that the presence of $\mathrm{oA} \beta$ increased the mRNA and protein expression levels of gp91phox and p47phox in the microglia; however, this increase was prevented by pre-treatment with resveratrol (Figs. 3 and 4). These results suggested that resveratrol inhibited oA $\beta$-induced microglial activation by inhibiting the expression of NADPH oxidase, and that the gp91phox and p47phox NADPH oxidase subunits were involved in this reaction.
A

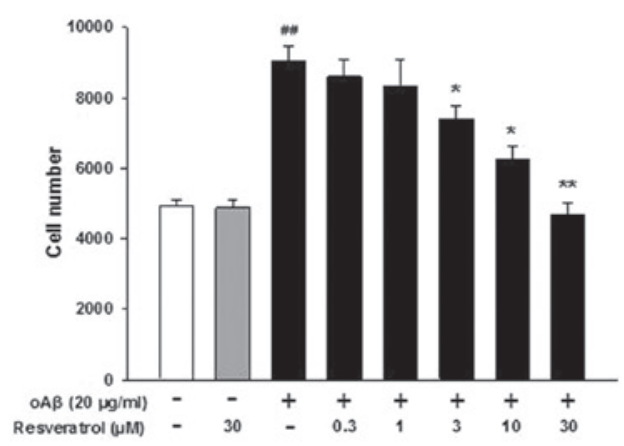

B

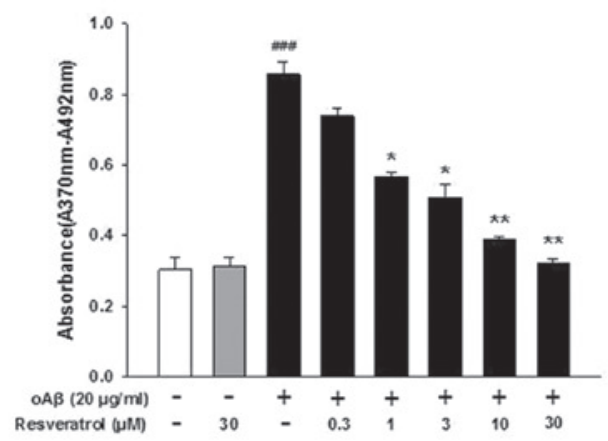

C

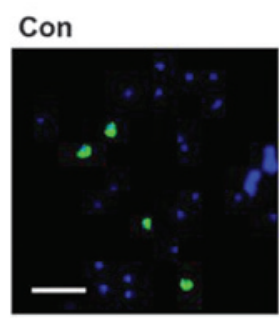

$\operatorname{Res}(30 \mu \mathrm{M})$

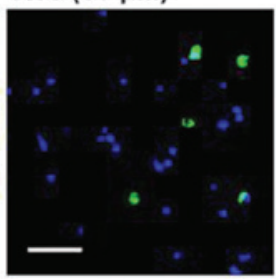

$\mathrm{OA} \beta$

$\mathrm{oA} \beta+\operatorname{Res}(3 \mu \mathrm{M})$

$\mathrm{oA} \beta+\operatorname{Res}(10 \mu \mathrm{M})$
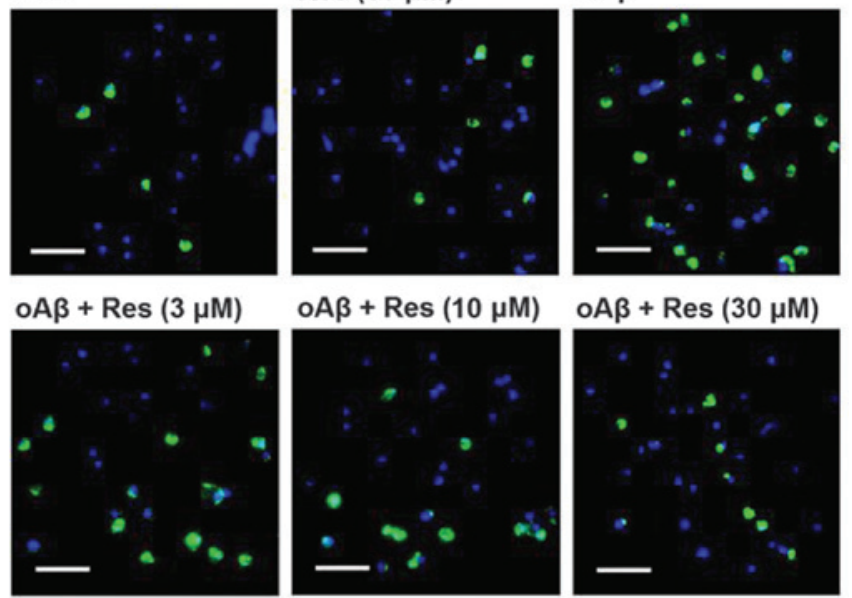

$\mathrm{OA} \beta+\operatorname{Res}(30 \mu \mathrm{M})$

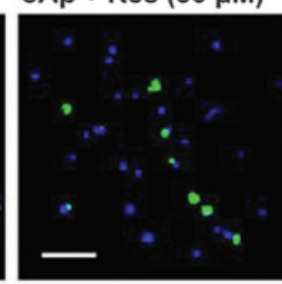

Figure 1. Effects of resveratrol on oA $\beta$-induced BV-2 microglial proliferation. $\mathrm{BV}-2$ microglial cultures were incubated with $20 \mu \mathrm{g} / \mathrm{ml} \mathrm{oA} \beta$, with or without various concentrations of resveratrol for $24 \mathrm{~h}$. Following the $24 \mathrm{~h}$ incubation, microglial cell proliferation was measured using (A) high-content screening and (B) BrdU incorporation colorimetric assay. (C) Fluorescence images of microglial cells double-labeled with Hoechst 33342 (blue) and BrdU (green) were acquired on an IN Cell Analyzer 2000 system. Scale bar=25 $\mu \mathrm{m}$. Data are presented as the mean \pm standard error of the mean from three independent experiments. ${ }^{\# \#} \mathrm{P}<0.01$ and ${ }^{\# \# \#} \mathrm{P}<0.001$, compared with the control group; ${ }^{*} \mathrm{P}<0.05$ and ${ }^{* *} \mathrm{P}<0.01$, compared with the $\mathrm{oA} \beta$ group. oA $\beta$, oligomeric amyloid $\beta$; BrdU, bromodeoxyuridine; Res, resveratrol; Con, control.

\section{Discussion}

Cell proliferation is a key aspect in microglial activation in response to brain damage or injury; proliferation can be quantified by cell counting or incorporation experiments, including BrdU or ${ }^{3} \mathrm{H}-\mathrm{TdR}$ assays (19). In addition, it has been reported 
A

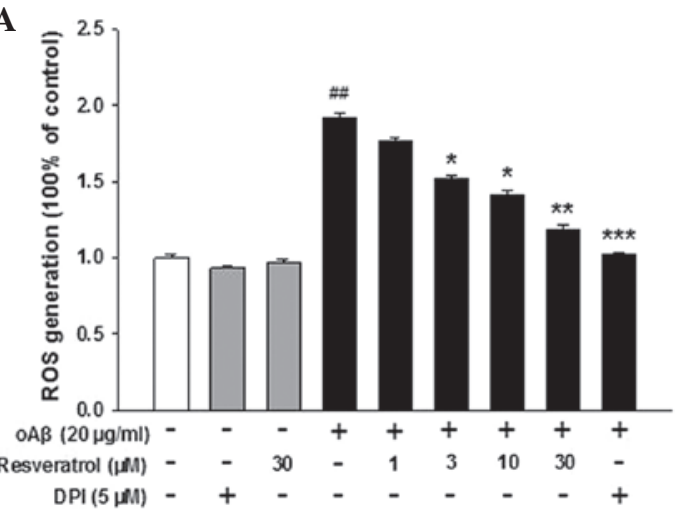

C

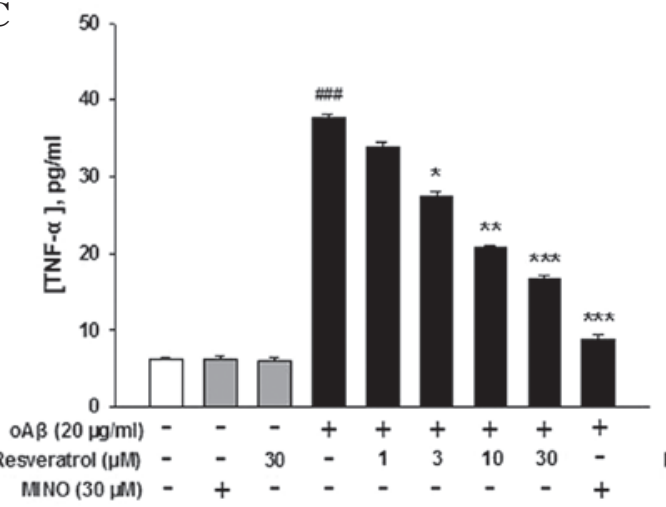

B

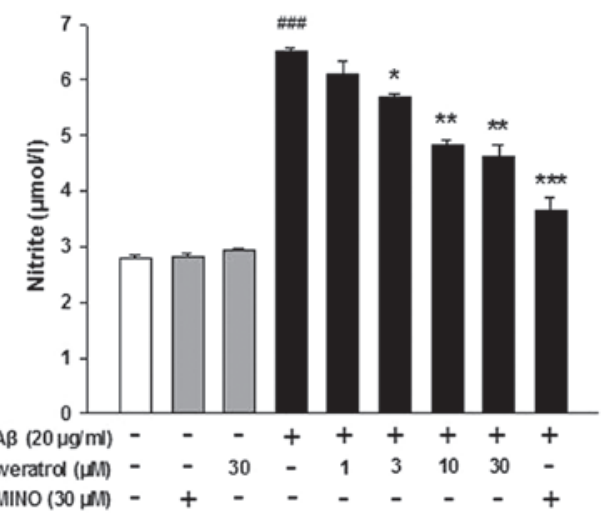

D

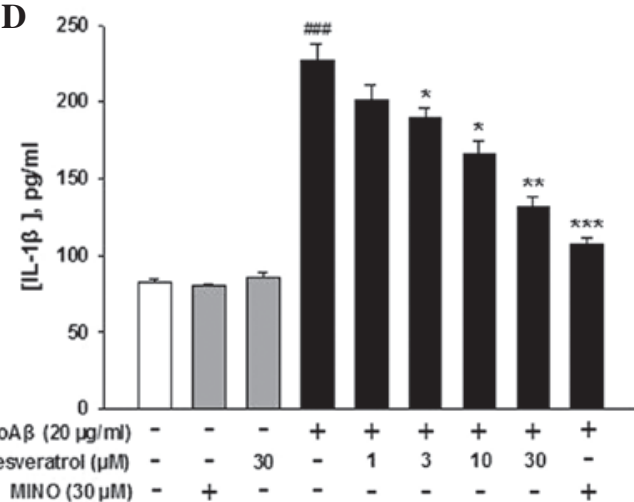

Figure 2. Effects of resveratol on oA $\beta$-induced pro-inflammatory mediator release in BV-2 microglia. Microglial cultures were incubated with $20 \mu \mathrm{g} / \mathrm{ml} \mathrm{oA} \beta$, with or without various concentrations of resveratrol for $2 \mathrm{~h}$ to measure ROS, and for $24 \mathrm{~h}$ to measure the levels of NO, TNF- $\alpha$ and IL-1 $1 \beta$. DPI (5 $\mu \mathrm{M})$ or MINO $(30 \mu \mathrm{M})$ were used as positive controls. Following incubation, the cell media were collected for measurement of the levels of (A) ROS, (B) NO, (C) TNF- $\alpha$ and (D) IL-1 $\beta$. Data are presented as the mean \pm standard error of the mean from three independent experiments. ${ }^{\# \#} \mathrm{P}<0.01$ and ${ }^{\# \# \#} \mathrm{P}<0.001$, compared with the control group; ${ }^{*} \mathrm{P}<0.05^{* *} \mathrm{P}<0.01$ and ${ }^{* * * *} \mathrm{P}<0.001$, compared with the oA $\beta$ group. oA $\beta$, oligomeric amyloid $\beta$; ROS, reactive oxygen species; NO, nitric oxide; TNF, tumor necrosis factor; IL, interleukin; DPI, diphenyleneiodonium; MINO, minocycline.

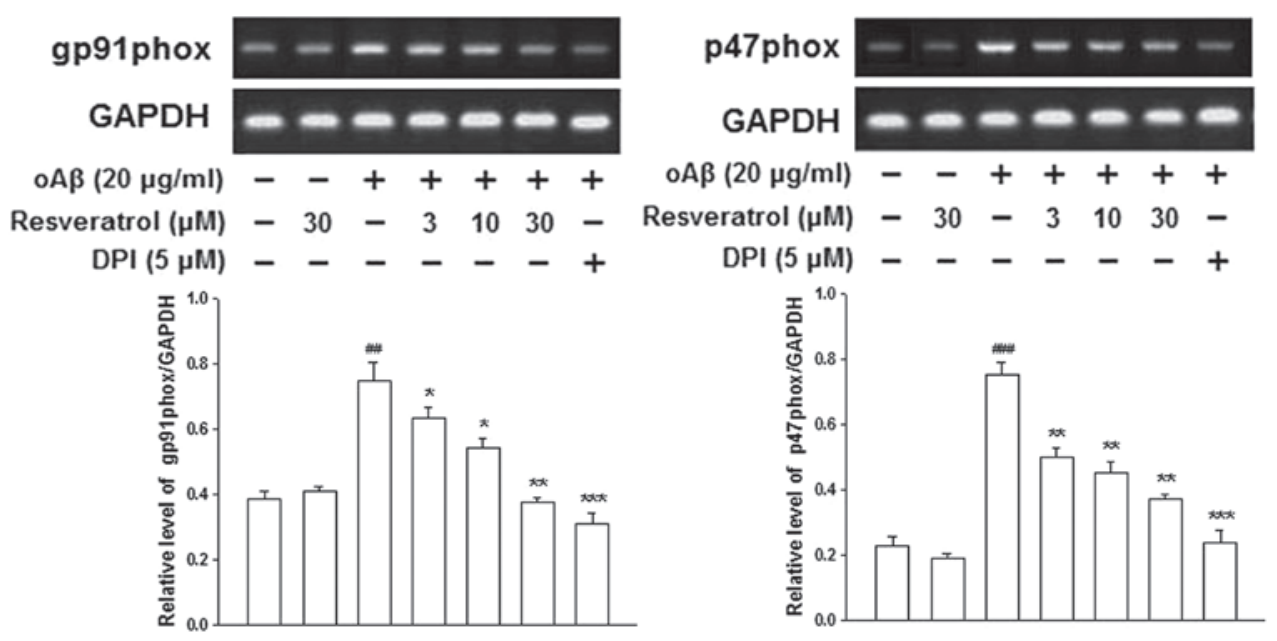

Figure 3. Effects of resveratrol on oA $\beta$-induced mRNA expression of the gp91phox and p47phox NADPH oxidase subunits in BV-2 microglial cells. The BV-2 microglial cells were treated with $20 \mu \mathrm{g} / \mathrm{ml} \mathrm{oA}$, with or without various concentrations of resveratrol or DPI $(5 \mu \mathrm{M})$ for $12 \mathrm{~h}$. Total RNA was extracted from the cells, and the mRNA expression levels of gp91phox and p47phox were measured using reverse transcription-polymerase chain reaction. GAPDH was used as an internal control. The ratio of densitometry values of gp91phox and p47phox, compared with GAPDH, were analyzed and normalized to each respective control group. Data are presented as the mean \pm standard error of the mean from three independent experiments. ${ }^{\# \#} \mathrm{P}<0.01$ and ${ }^{\# \# \#} \mathrm{P}<0.001$, compared with the control group; ${ }^{*} \mathrm{P}<0.05^{* * *} \mathrm{P}<0.01$ and ${ }^{* * * *} \mathrm{P}<0.001$, compared with the $\mathrm{oA} \beta$ group. $\mathrm{A} \beta$, oligomeric amyloid $\beta$; DPI, diphenyleneiodonium.

that $\mathrm{oA} \beta$ induces the proliferation of microglia (20). A previous study demonstrated that the pro-proliferative activity of oA $\beta$ is regulated by NADPH oxidase (21). The present study investigated the effects of resveratrol on oA $\beta$-stimulated microglial proliferation, using an HCS system and BrdU assay. The results demonstrated that $\mathrm{OA} \beta$ induced the proliferation of microglia, and this effect was markedly inhibited by resveratrol, suggesting that the anti-inflammatory effect of resveratrol 

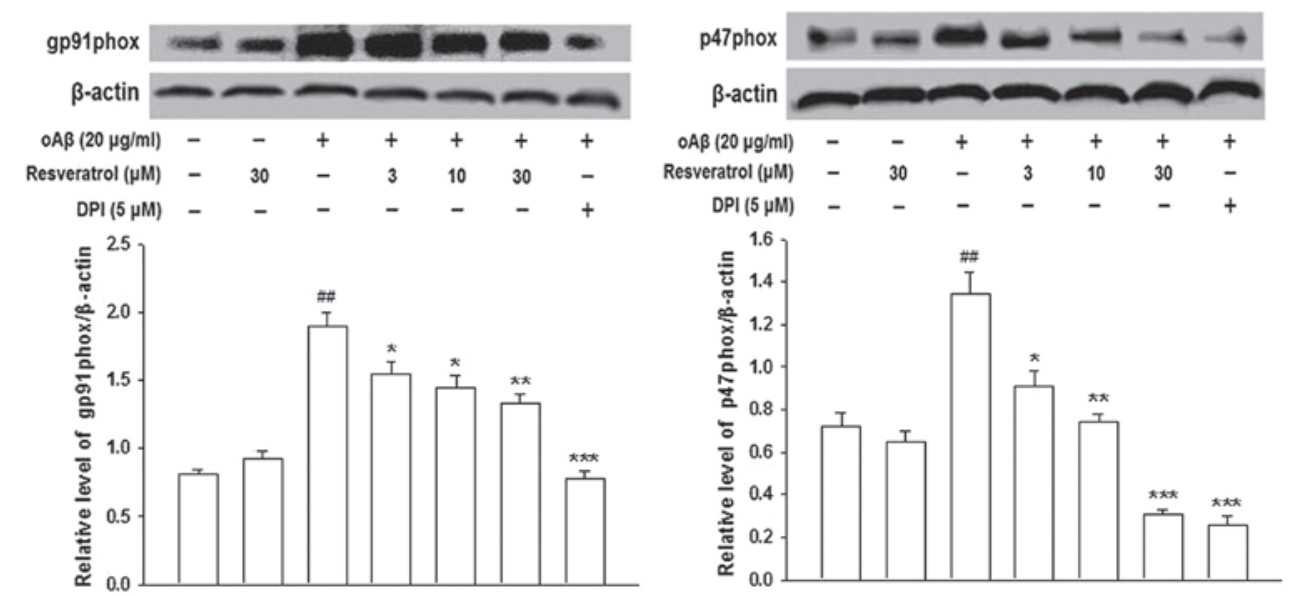

Figure 4. Effects of resveratrol on oA $\beta$-induced protein expression of the gp91phox and p47phox NADPH oxidase subunits in BV-2 microglial cells. The BV-2 microglial cells were treated with $20 \mu \mathrm{g} / \mathrm{ml} \mathrm{oA} \beta$, with or without various concentrations of resveratrol or DPI $(5 \mu \mathrm{M})$ for $24 \mathrm{~h}$. Whole cell lysates were harvested to perform western blot analysis. $\beta$-actin was used as an internal control. The ratio of densitometry values of gp91phox and p47phox, compared with $\beta$-actin, were analyzed and normalized to each respective control group. Data are presented as the mean \pm standard error of the mean from three independent experiments. ${ }^{\# \#} \mathrm{P}<0.01$, compared with the control group; ${ }^{*} \mathrm{P}<0.05{ }^{* *} \mathrm{P}<0.01$ and ${ }^{* * * *} \mathrm{P}<0.001$, compared with the oA $\beta$ group. oA $\beta$, oligomeric amyloid $\beta$; DPI, diphenyleneiodonium.

may contribute to the inhibition of microglial proliferation. To the best of our knowledge, this is the first study to report these findings.

Previous studies have demonstrated that microglia are the predominant source of NADPH oxidase in the brain $(22,23)$. Among various neurotoxic factors produced by activated microglia, NADPH oxidase-derived ROS are important in microglia-mediated neuroinflammation. ROS are involved in host defense systems by destroying invading pathogens and inducing the production of various antioxidant enzymes in host cells (24). Previous studies have revealed that ROS also act as secondary messengers to enhance gene expression by encoding a variety of pro-inflammatory factors (25). The present study demonstrated that resveratrol reduced ROS production in oA $\beta$-activated BV-2 microglial cells. Although resveratrol has previously been reported to reduce oxidative effects by functioning as a ROS scavenger (26), a novel finding in the present study was that resveratrol inhibited oA $\beta$-induced activation of microglial NADPH oxidase and the consequent production of ROS.

Previous studies have reported that resveratrol downregulates the mRNA expression of NADPH oxidase 4, which is a homolog of gp91phox and is the most abundant NADPH oxidase-catalytic subunit in human umbilical vein endothelial cells (27). However, the role of resveratrol in the oA $\beta$-induced microglial expression of NADPH oxidase subunits remains to be elucidated. The molecular mechanistic experiments performed in the present study demonstrated that resveratrol inhibited the oA $\beta$-induced mRNA and protein expression of the gp91phox and p47phox NADPH oxidase subunits, leading to decreased ROS production. Although resveratrol affects the expression of gp91phox, which is the dominant NADPH oxidase and the major superoxide-generating enzyme in inflamed microglia (28), the effects of resveratrol on the phosphorylation and translocation of NADPH oxidase subunits and on NADPH oxidase activity require further investigation.

The results of the present study demonstrated that resveratrol exerted potent inhibitory effects on the oA $\beta$-induced production of NO, TNF- $\alpha$ and IL- $1 \beta$ in the BV- 2 microglia cultures. These findings were concordant with the results of previous studies, in which resveratrol was found to inhibit the LPS-induced production of pro-inflammatory factors in primary microglia or microglial cell lines $(8,9)$. NO, TNF- $\alpha$ and IL- $1 \beta$ are regarded as important substances in microglial activation $(29,30)$. Our previous study demonstrated that $\mathrm{oA} \beta$ alone induces the production of these pro-inflammatory factors in microglia, and NADPH oxidase is important in these effects (16). Accordingly, in the present study, inhibition of NADPH oxidase by resveratrol decreased the levels of pro-inflammatory factors released by the oA $\beta$-activated microglial cells. It has been widely accepted that increased levels of cytokines and chemokines are released by activated microglia, which result in chronic neuroinflammation and are partially responsible for neuronal damage and neurodegeneration in the brains of patients with AD (31). This suggests that the inhibitory effects of resveratrol on oA $\beta$-induced microglial pro-inflammatory factor release partly contribute to its neuroprotective and cognitive improvement effects in $\mathrm{AD}$.

In conclusion, the present study demonstrated that resveratrol inhibited oA $\beta$-induced $\mathrm{BV}-2$ microglial activation, resulting in the inhibition of cell proliferation and reductions in the secretion of various pro-inflammatory factors. Subsequent mechanistic investigation demonstrated that the inhibitory effects of resveratrol on microglial activation were mediated by NADPH oxidase. Furthermore, the gp91phox and $\mathrm{p} 47$ phox NADPH oxidase subunits were important in these effects. These results suggest that resveratrol is a valuable natural product, possessing therapeutic potential against AD.

\section{Acknowledgements}

The present study was supported by the China Postdoctoral Science Foundation (grant no. 2014T70204), the National Natural Science Foundation of China (grant no. 81460665), the Natural Science Foundation of Ningxia (grant no. NZ14059) 
and the Special Talent Research Project of Ningxia Medical University (grant no. XT201316).

\section{References}

1. Glass CK, Saijo K, Winner B, Marchetto MC and Gage FH: Mechanisms underlying inflammation in neurodegeneration. Cell 140: 918-934, 2010.

2. Kawabori M and Yenari MA: The role of the microglia in acute CNS injury. Metab Brain Dis 30: 381-392, 2014.

3. Block ML, Zecca L and Hong JS: Microglia-mediated neurotoxicity: Uncovering the molecular mechanisms. Nat Rev Neurosci 8: 57-69, 2007.

4. Markus MA and Morris BJ: Resveratrol in prevention and treatment of common clinical conditions of aging. Clin Interv Aging 3: 331-339, 2008

5. Ponzo V, Soldati L and Bo S: Resveratrol: a supplementation for men or for mice? J Transl Med 12: 158, 2014.

6. de la Lastra CA and Villegas I: Resveratrol as an anti-inflammatory and anti-aging agent: Mechanisms and clinical implications. Mol Nutr Food Res 49: 405-430, 2005.

7. Lorenz P, Roychowdhurys, Engelmann M, Wolf G and Horn TF: Oxyresveratrol and resveratrol are potent antioxidants and free radical scavengers: Effect on nitrosative and oxidative stress derived from microglial cells. Nitric Oxide 9: 64-76, 2003.

8. Bi XL, Yang JY, Dong YX, Wang JM, Cui YH, Ikeshima T, Zhao YQ and Wu CF: Resveratrol inhibits nitric oxide and TNF-alpha production by lipopolysaccharide-activated microglia. Int Immunopharmacol 5: 185-193, 2005.

9. Candelario-Jalil E, de Oliveira AC, Gräfs, Bhatia HS, Hüll M, Muñoz E and Fiebich BL: Resveratrol potently reduces prostaglandin E2 production and free radical formation in lipopolysaccharide-activated primary rat microglia. J Neuroinflammation 4: 25, 2007.

10. Lu X, Ma L, Ruan L, Kong Y, Mou H, Zhang Z, Wang Z, Wang JM and Le Y: Resveratrol differentially modulates inflammatory responses of microglia and astrocytes. J Neuroinflammation 7: 46, 2010.

11. Zekry D, Epperson TK and Krause KH: A role for NOX NADPH oxidases in Alzheimer's disease and other types of dementia? IUBMB Life 55: 307-313, 2003.

12. Capiralla H, Vingtdeux V, Zhao H, Sankowski R, Al-Abed Y, Davies $\mathrm{P}$ and Marambaud P: Resveratrol mitigates lipopolysaccharide- and $\mathrm{A} \beta$-mediated microglial inflammation by inhibiting the TLR4/NF- $x$ B/STAT signaling cascade. J Neurochem 120: 461-472, 2012

13. Choi SH, Aid S, Kim HW, Jackson SH and Bosetti F: Inhibition of NADPH oxidase promotes alternative and anti-inflammatory microglial activation during neuroinflammation. J Neurochem 120: 292-301, 2012.

14. McLean CA, Cherny RA, Fraser FW, FullersJ, Smith MJ, Beyreuther K, Bush AI and Masters CL: Soluble pool of Abeta amyloid as a determinant of severity of neurodegeneration in Alzheimer's disease. Ann Neurol 46: 860-866, 1999.

15. Mc Donald JM, Savva GM, Brayne C, Welzel AT, Forster G, Shankar GM, Selkoe DJ, Ince PG and Walsh DM; Medical Research Council Cognitive Function and Ageing Study: The presence of sodium dodecyl sulphate-stable Abeta dimers is strongly associated with Alzheimer-type dementia. Brain 133: $1328-1341,2010$
16. Li J, Yang JY, Yao XC, Xue X, Zhang QC, Wang XX, Ding LL and $\mathrm{Wu} C F$ : Oligomeric A $\beta$-induced microglial activation is possibly mediated by NADPH oxidase. Neurochem Res 38: 443-452, 2013

17. BargersW and Harmon AD: Microglial activation by Alzheimer amyloid precursor protein and modulation by apolipoprotein $\mathrm{E}$. Nature 388: 878-881, 1997.

18. Groemping $\mathrm{Y}$ and Rittinger $\mathrm{K}$ : Activation and assembly of the NADPH oxidase: A structural perspective. Biochem J 386: 401-416, 2005.

19. Giuliani F, Hader W and Yong VW: Minocycline attenuates $\mathrm{T}$ cell and microglia activity to impair cytokine production in T cell-microglia interaction. J Leukoc Biol 78: 135-143, 2005.

20. Maezawa I, Zimin PI, Wulff H and Jin LW: Amyloid-beta protein oligomer at low nanomolar concentrations activates microglia and induces microglial neurotoxicity. J Biol Chem 286: 3693-3706, 2011.

21. Jekabsone A, Mander PK, Tickler A, Sharpe M and Brown GC: Fibrillar beta-amyloid peptide Abeta1-40 activates microglial proliferation via stimulating TNF-alpha release and $\mathrm{H}_{2} \mathrm{O}_{2}$ derived from NADPH oxidase: A cell culture study. J Neuroinflamm 3: 24, 2006.

22. Green SP, Cairns B, Rae J, Errett-Baroncini C, Hongo JA, Erickson RW and Curnutte JT: Induction of gp91-phox, a component of the phagocyte NADPH oxidase, in microglial cells during central nervous system inflammation. J Cereb Blood Flow Metab 21: 374-384, 2001.

23. Klegeris A and McGeer PL: Rat brain microglia and peritoneal macrophages show similar responses to respiratory burst stimulants. J Neuroimmunol 53: 83-90, 1994.

24. Babior BM: Oxidants from phagocytes: Agents of defense and destruction. Blood 64: 959-966, 1984.

25. Qin L, Liu Y, Wang T, Wei SJ, Block ML, Wilson B, Liu B and Hong JS: NADPH oxidase mediates lipopolysaccharide-induced neurotoxicity and proinflammatory gene expression in activated microglia. J Biol Chem 279: 1415-1421, 2004.

26. Leonard SS, Xia C, Jiang BH, Stinefelt B, Klandorf H, Harris GK and Shi X: Resveratrol scavenges reactive oxygen species and effects radical-induced cellular responses. Biochem Biophys Res Commun 309: 1017-1026, 2003.

27. Spanier G, Xu H, Xia N, Tobias S, Deng S, Wojnowski L, Forstermann $\mathrm{U}$ and $\mathrm{Li} \mathrm{H}$ : Resveratrol reduces endothelial oxidative stress by modulating the gene expression of superoxide dismutase 1 (SOD1), glutathione peroxidase 1 (GPx1) and NADPH oxidase subunit (Nox4). J Physiol Pharmacol 60 (Suppl 4): 111-116, 2009.

28. Banati RB, Gehrmann J, Schubert P and Kreutzberg GW: Cytotoxicity of microglia. Glia 7: 111-118, 1993.

29. Hur J, Lee P, Kim MJ, Kim Y and Cho YW: Ischemia-activated microglia induces neuronal injury via activation of gp91phox NADPH oxidase. Biochem Biophys Res Commun 391: 1526-1530, 2010.

30. Wilms H, Sievers J, Rickert U, Rostami-Yazdi M, Mrowietz U and Lucius R: Dimethylfumarate inhibits microglial and astrocytic inflammation by suppressing the synthesis of nitric oxide, IL-1beta, TNF-alpha and IL-6 in an in-vitro model of brain inflammation. J Neuroinflammation 7: 30, 2010.

31. Eikelenboom P, Veerhuis R, Scheper W, Rozemuller AJ, van Gool WA and Hoozemans JJ: The significance of neuroinflammation in understanding Alzheimer's disease. J Neural Transm 113. 1685-1695, 2006. 